\section{EUROPEAN RED MITE \\ Control with Petroleum Oils}

\author{
HAROLD F. MADSEN - TIM T. Y. WONG
}

$\mathbf{T}$ HE PROBLEM of spider mite resistmeans of mite control. In 1963, plots were established in a Red Delicious apple orchard to evaluate one new acaricide and several oils of varying viscosity and unsulfonated residue against the European red mite. Among several acaricides that had been studied in 1962, the most promising material was Morestan, a new cyclic carbonate insecticide.

This compound was included in the 1963 plots with the following schedule: Morestan alone, Morestan plus oil, and an early spray of Morestan followed by oil. The objective of these studies was to determine whether a selection of resistant strains of mites could be delayed by using the new compound in combination with oil or by using it but once during the season. It is planned to continue this program on the same trees for several seasons or until data are accumulated which indicate whether resistance has or has not developed.

The plots were established in a mature Red Delicious apple orchard which had a heavy mite infestation the previous season. The treatments were applied to single trees with five replications in a randomized block design. At each application the gallonage averaged six per tree, and all materials were applied with a conventional power sprayer.

The mite population was estimated by taking counts at biweekly intervals. Twenty leaves were picked at random from each replicate tree, and the mites were removed in the laboratory by means of a mite brushing machine.

The various plots were treated at different intervals depending upon the purpose of the experiments. The trees receiving the Morestan combinations were sprayed at the petal fall period. One plot also received an oil treatment at this time. The other oils were applied to plots were resprayed within two weeks or when the mite count reached an economic level. The data obtained are summarized in the table.

Mite control was excellent on trees sprayed experimentally with Morestan.
Since the plan was to use two seasonal toxic for practical use. ance to acaricides has stimulated interest in the use of petroleum oils as a when the mites became numerous and sprays of Morestan on one plot and another was to receive one treatment followed by oil, these trees were retreated in August. In all probability a single spray would have given adequate control for the season, as the mite count at the time of retreatment was below an economic level. The combination of Morestan and oil gave excellent control, but was phytotoxic. The foliage turned brown with necrotic spots and the young fruit was badly russetted. No further treatments were made on these trees as this combination was too phyto-

The plots which received the various oils were all retreated within two weeks, since previous work had shown that this schedule gave the best control. This tim. ing is necessary because oils kill the active stages of mites and some but not all of the eggs. The immobile molting stages are not harmed; and because these mites resume activity along with young nymphs which hatch from the eggs, it is necessary to apply a second spray. Good control was obtained with the oils of varying viscosity with the exception of the light (57.6 viscosity) Humble oil. This plot required three sprays to hold mites below treatment level. It is possible that oils below 70 viscosity are too light for effective mite control under California conditions. The two 500 viscosity oils were compared because one (Shell Carnea) has a low unsulfo-

SUMMARY OF EUROPEAN RED MITE PLOTS-WATSONVILLE-1963

\begin{tabular}{|c|c|c|c|c|c|c|c|c|c|c|c|}
\hline \multirow{2}{*}{$\begin{array}{l}\text { Materials and } \\
\text { Dosage per } 100 \text { gals. }\end{array}$} & \multirow{2}{*}{$\begin{array}{l}\text { Applica- } \\
\text { tion } \\
\text { Dates }\end{array}$} & \multicolumn{10}{|c|}{ European red mite count } \\
\hline & & $4 / 30$ & $5 / 7$ & $5 / 23$ & $6 / 4$ & $6 / 18$ & $7 / 3$ & $7 / 17$ & $7 / 31$ & $8 / 14$ & $8 / 28$ \\
\hline $\begin{array}{l}\text { Morestan I lb. } \\
25 \% \text { wettable } \\
1 \text { gallon } 70 \text { vis. }\end{array}$ & April 30 & & & & & & & & & & \\
\hline Penn. Superior oil & Augusł 7 & 10.6 & 0.0 & 0.02 & 0.1 & 0.30 & 0.61 & 4.72 & 2.36 & 1.33 & 0.7 \\
\hline $\begin{array}{l}\text { Morestan } 1 \mathrm{lb} . \\
25 \% \text { wettable } \\
+1 \text { gal. } 70 \text { vis. } \\
\text { Penn. Superior oil }\end{array}$ & April 30 & 6.9 & 0.0 & 0.05 & 0.0 & 0.44 & 0.57 & 3.90 & 5.42 & 11.32 & $2.5^{\star}$ \\
\hline $\begin{array}{l}\text { Morestan } 1 \mathrm{lb} \text {. } \\
25 \% \text { wettable }\end{array}$ & $\begin{array}{l}\text { April } 30 \\
\text { August } 7\end{array}$ & 5.1 & 0.0 & 0.04 & 0.05 & 0.08 & 0.23 & 1.80 & 1.84 & 1.36 & 0.7 \\
\hline $\begin{array}{l}1 \text { gallon } 70 \text { vis. } \\
\text { Penn. Superior oil }\end{array}$ & $\begin{array}{l}\text { April } 30 \\
\text { July } 10\end{array}$ & 6.2 & 0.7 & 0.25 & 1.1 & 1.44 & 3.82 & 1.80 & 1.26 & 2.32 & 3.2 \\
\hline $\begin{array}{l}1 \text { gallon } 997 \text { vis. } \\
\text { Moyer oil }\end{array}$ & $\begin{array}{l}\text { June } 26 \\
\text { July } 10\end{array}$ & & 24.2 & 7.02 & 11.2 & 46.72 & 7.61 & 1.70 & 0.12 & .90 & 1.9 \\
\hline $\begin{array}{l}1 \text { gallon } 57.6 \text { vis. } \\
\text { Humble oil }\end{array}$ & $\begin{array}{l}\text { June } 6 \\
\text { June } 26 \\
\text { August } 7\end{array}$ & & & & 15.4 & 3.57 & 1.42 & 2.77 & 6.60 & .76 & 3.2 \\
\hline $\begin{array}{l}1 \text { gallon } 507 \text { vis. } \\
\text { Moyer oil }\end{array}$ & $\begin{array}{l}\text { June } 6 \\
\text { June } 26\end{array}$ & & & & 13.0 & 0.80 & 1.35 & 1.49 & 0.40 & 2.97 & 1.9 \\
\hline $\begin{array}{l}1 \text { gallon } 500 \text { vis. } \\
\text { Shell Carnea oil }\end{array}$ & $\begin{array}{l}\text { June } 6 \\
\text { June } 26\end{array}$ & & & & 15.8 & 22.66 & 0.56 & 0.51 & 0.26 & 2.35 & 1.3 \\
\hline
\end{tabular}

* Numerous Typhlodromus mites present. better than that obtained with the oils of a high unsulfonated residue. The data show no differences in mite control with use of oils ranging from 70 to 991 viscosity. It had been theorized that heavy oils would give better mite control because they persist longer on foliage; however, data over three seasons do not show improved insect or mite control with oils of high viscosity. The data obtained thus far must be supplemented with deposit analyses, in order to find reasons why certain oils behave as they do. The initial deposit of oils may be the important factor rather than persistence on leaves.

Surprisingly good control was obtained with the petal fall application of Penn. Salt 70 viscosity oil. The trees showed low mite populations until July, and a second spray provided seasonal control.

Early season timing for oil sprays is deserving of further study as a preventive treatment. Most previous oil treatments have been applied as curative.

In addition, the long-term effect of oils on fruit trees needs to be determined along with compatibility of oils with insecticides and fungicides that may be combined with them.

Harold F. Madsen is Associate Entomologist, and Tim T. Y. Wong is Laboratory Technican II, Dept. of Entomology, University of California, Berkeley. nated residue of 77 as compared with 92 for the Moyer 500 viscosity oil. There was no difference in the control obtained, but the Shell Carnea oil was phytotoxic, causing a marginal leaf burn and yellow spotting of the fruit. There seems to be no reason to use an oil of this low unsulfonated residue since the control was no

CALIFORNIA AGRICULTURE, MARCH, 1964 